\title{
Nedainova T. B.
}

\section{IS SECONDARY SCHOOL LITERATURE EDUCATION GOING THROUGH A CRISIS?}

Economic crisis, educational crisis - crisis in the souls. Understanding the causes of these crises and the ways to deal with them are of topical significance today. Unfortunately, literature education at a secondary school level, which is the basis for the humanitarian development of an individual, establishment of his/her inner world and moral values, also exhibits the signs of crisis. Significance of reading agenda is increasing also due to the ample international research that revealed the lack of interest to reading in high school in the majority of developed countries, despite the attention these countries afford reading fluency in primary school. Teaching methodology experts, educators, sociologists, and professionals in other related spheres emphasize that secondary school children do not read the works of even well-recognized representatives of classical literature. The opinions vary from stating that reading culture is in crisis to proclaiming the development of a new reading model emerging in the modern information society.

Significant changes have occurred in the social and moral atmosphere, romanticism is out of fashion, such qualities as unselfishness, mercy, self-sacrifice, kindness, and patriotism are a rare commodity, while universal values and ideals described in the best examples of world literature and included in secondary school syllabi have been dramatically reconsidered. At present, we have to agree that the $21^{\text {st }}$ Century started with the direct and harsh confrontation of the civilized and the barbaric. On the one hand, each individual can learn about the classical and modern works of art, can read any piece of writing or find the book he/she likes, discuss problems with people who live in different cities and countries. On the other, on a regular basis, we face indifference, extreme individualism, lack of principles, acts of 
vandalism, violence, and homicides, which make our blood run cold. Under such circumstances, secondary school literature education and, speaking more broadly, humanitarian education, become a lifesaver in the whirl of passions, conflicts, needs, and desires. These issues have set the stage for investigating issues related to reading as a basic educational component today.

The goal of the article is to analyze the changes that have occurred in the organization of students' reading and to describe several methodological approaches to solving reading-related problems in accord with new sociocultural conditions.

The means of cultivating students' interest in reading were discussed by the famous Ukrainian and Russian teachers and methodologists G. I. Byelen'ky, L. H. Zhabyts'ky, I. S. Zbars'ky, O. O. Isaeva, V. A. Levidov, L. F. Miroshnychenko, et al., as well as by the foreign researchers M. Graves, M. A. Embi, et al. In their works, the development of reading in the course of secondary school literature education was considered, as well as the role of the literature teacher in promoting students' interest in reading and enhancing positive reading culture were described.

Modern studies in the methodology of teaching literature are mostly concerned with the development of skills necessary for interpreting and analyzing fiction (including authentic and translated literary works) and for conducting comparative, philological, culturological, and other kinds of analyses; they also pay much attention to appealing to various arts in the literature classroom, and so on. But still, the main objective of any literature teacher, irrespective of his/her methodological approach or the methods and techniques he/she applies in the classroom, is the development of the student's personality, his/her inner world, the raising of "a man of culture". Developing the feelings and imagination of students, deepening their literature works comprehension, literature classes are bound to impact the formation of students' value orientations, their attitude to the world, country, work, family, religion, art, culture, and to themselves.

It is well-known that a deeper understanding of the content of any literary work or special text requires much work on the part of the reader, since it includes not only extracting new information, but also thinking it through, readiness for the inner 
change, reconsideration of one's own views and beliefs. In Ukrainian secondary schools, such classes as Ukrainian Literature, World Literature, and an integrated course called Literature are taught simultaneously, thus creating a unified system of literature education. These subjects are tied together by universal spiritual and moral values, as well as worldviews, methodological approaches to literary texts' analysis and to conducting literature classes.

In the journals concerned with the subject, namely Vsesvitnya Literatura $v$ Suchasniy Shkoli (World Literature in Modern School), Zarubizhna Literatura $v$ Shkolakh Ukrayiny (Foreign Literature in Ukrainian Secondary Schools), Rosiys 'ka Slovesnist' v Shkolakh Ukrayiny (Russian Language and Literature in Ukrainian Schools), Vsesvitnya Literatura ta Kultura (World Literature and Culture), the debates about creating the course of literature and, a literature lesson in particular, which will prove efficient in motivating the students to read, are in progress. These discussions are focused on the ways and methods of the analysis of the texts of fiction; the analysis and interpretation of literary works; the methods of literary text analysis used at secondary school and university levels; literature teaching methodology as a science and an art; the challenges of the contemporary literature lesson, etc.

Teaching literature is undoubtedly a very complex and multi-faceted process. One of its tasks is to gradually develop students' skills and abilities to analyze and interpret a literary work. The guidelines regulating literature teachers' work are described in The State Standards, syllabi, and in the draft of The Concept of Secondary School Literature Education in Ukraine. These documents determine the content and stages of school children's literary development for each grade, and yet the fact that every child in his/her school life moves along his own "reader's pathway" is becoming increasingly self-evident. Some fifth-graders have developed reading interests and habits, as well as their own reading preferences, including literary works specified in the course syllabus and even beyond it. On the other hand, there are students who, by the time they graduate from secondary school, cannot read accurately, automatically, and with appropriate expression, let alone reading 
comprehension skills or the ability to evaluate and interpret literature. Perhaps, children today do not fit into any, even the most thoroughly designed, system of learning. More often than not, the attempts of teachers to rely on the known patterns of teaching and learning fail when it comes to the real process of child's individual development in the course of education, including reading practice.

At the turn of the 1980s and 1990s, when first democratic ideas made their way into education, new personality-oriented paradigm emerged, bringing along innovative concepts that formed the basis for the notion of "understanding pedagogy" and the work of those teachers who are searching for the alternative approaches to the methodology of teaching literature:

- the child is the subject of education; in the center of the educational process is a real child and his/her potential (which means taking the child as he/she is);

- the importance of drawing on child's individual experience in education; and

- the necessity to take into consideration child's abilities, needs, interests, as well as his/her rights [5, p. 227].

When developing the modern methodology of teaching literature in secondary schools, the perception of literary works both in terms of their genre, as well as the themes portrayed is viewed from the point of view of the students' developmental profile. Along the same lines, students are now given the right to choose among the literary work of this or that author and are offered a list of texts for extracurricular and individual reading. Secondary schools today are supplied with new literature textbooks, the content and design of which could easily compete with the ones published in the Soviet times. Among the reasons why the modernization of literary education and the attempts to tackle literary reading issues remain patchy are a number of inconsistencies, which signify not so much the existence of the crisis in literature education, but the necessity to change the attitudes towards this process. These are the inconsistencies between:

- the contemporary sociocultural requirements to give students free choice with regard to the trajectory of the literature education and the development of their 
creativity and the strict requirements imposed by the syllabus as concerns the study of literary works;

- the useless attempts of the methodologists to ground their work on the defined patterns and principles of teaching/learning literature in secondary school and the actual processes of students' self-development and self-education; and

- the longing of literature teachers to use innovations in the educational process and the existence of numerous restrictions, which virtually limit teachers' freedom in developing new content and improving methodology.

The inconsistences and challenges revealed above require that different priorities be established in the assessment of the secondary school literature education. Perhaps, students should be motivated to read not only fiction, but also scientific, specialized, and references books, etc. The latter can have positive impact on the intellectual and moral growth of an individual, help adapt to various real-life situations in accord with the student's goals, stand in life, and moral values. At present, the book is no longer the only source of knowledge. Computers, the Internet, television, and other mass media have definitely influenced the reading agenda in the world. There is no doubt that the book and the process of reading it is the best means of upbringing and teaching children. On the other hand, we have to face the fact that now students have the possibility to choose between reading a paper book, its e-version, or even learning about its content from a reader's digest or anthology. This latter option may well be seen as a way-out for the students who are poor readers and are unlikely to ever read the great L. Tolstoy's novel Voyna i Mir (War and Peace) unabridged. What is important here is that the teacher has to learn how to work with those students who have not read the text and are, unfortunately, unwilling to do so because, as they themselves say, they have seen a movie or read a critical article about it. This group of students is quite numerous, and the methodology of teaching literature will have to deal with them sooner or later.

Reading-related problems are among the "eternal" problems of teaching literature at school. It is critical to realize that there emerged a new kind of studentsreaders who are characterized by the pragmatic attitude to reading and low need for 
"serious" reading. They also demonstrate lack of interest in poetry and low reader's independence. At the same time, the range of means for reading various kinds of texts, namely technical, medical, specialized, political, etc., has increased. Adventure books, fantasy, detective stories, etc. are traditionally among the priority genres. It also has to be emphasized that today high school students end up reading more than they are supposed to according to the secondary school curriculum. They do so to prepare various reports, write essays and other projects, thus, reading more and not only fiction, but specialized literature as well. This causes overload, because the students sometimes have to prepare $5-6$ reports at a time, which consequently may lead to students' aversion to reading.

"The book environment" of the students is also undergoing profound changes. Individual socialization is more and more influenced by the mass media. Besides home library, children nowadays can make use of video collections, audio libraries, and, certainly, the Internet. Television, which is much more popular among students than books, contributes to the formation of so-called "lazy" readers, who can read, but are just unwilling to do so. The way people perceive the printed text and information is being transformed as well. It is becoming more fragmentary, superficial, and mosaic-like. It is harder for children to concentrate on longer texts (e.g., novels, stories), while they are becoming more attracted to the genres widely represented on TV (detective stories, thrillers, TV novels, horror films).

Teachers today are afforded a wide range of opportunities for creativity, but they are restricted by the students' unwillingness to read the literary works determined by the syllabus, lack of the literature environment for the interaction of students within and outside school, the destruction of family reading traditions. The aesthetic and moral evolution of students-readers (namely, in their early and late adolescence) proceeds from empathy to the evaluation of a literary work, from discussing the plot to the analysis of the characters and the author's attitude to them, from understanding the main themes and ideological and artistic content of the text to the development of their own interpretation of the piece of writing. The primary objective in this process is the actualization of the moral themes brought up in a 
literary work. The reader's interpretation must be compared and contrasted with the academic understanding of the text and its interpretations in music, graphic arts, theatre, cinema, etc. Any literary work is always studied in the classroom through the lens of the world and national culture, of the entire epoch or of an individual person. Moreover, the teacher should not forget that the perception of a literary work can change with student's age. Many teachers of language arts admit that modern students interpret literary works without taking into consideration the historical and cultural peculiarities of the epoch when it was created or tend to discuss the moral themes raised by the author from the position of today's world.

To illustrate the point, I will provide some examples from my own teaching experience, including literature classes in secondary schools and seminars with the students of university language and literature departments. For instance, most schoolchildren and university students cannot understand what was so special in Tatyana Larina's expression of love to Onegin (A. Pushkin, Eugene Onegin), why Katerina's life from N. Ostrovky's Groza had such a tragic ending ("she could live happily being in love with both Tikhon and Boris"), why Bazarov, "being a bad son, friend, and beloved, is still a positive literary character" (I. Turgenev's Fathers and Sons), why Mr. Higgins had to marry Eliza, "if he did not promise anything to her, and it was just an experiment" (B. Show's Pygmalion). Such examples are numerous, and they demonstrate that the literature teacher has an important task of correcting and enhancing students' understanding of true values. Therefore, it is becoming more and more obvious that the approach a literature teacher chooses to interpret a literary work should be based not only on its ideological and artistic values, but, rather, on the uniqueness of young readers' perception. More precisely, the teacher should pay special attention to "the weak links" of students' insufficiently developed artistic and aesthetic tastes, interests, cognitive abilities, their cultural and literary development in general.

Today certain practical experience of fostering students' interest in reading has been accumulated. It includes various ways of motivating children to read, modernizing the learning materials used, and improving the educational techniques 
designed to work with the text. But in most research works, as well as in teaching practice, reading is seen as a pedagogical phenomenon. Consequently, enhancing students' interest in reading usually occurs in schools and libraries. But a more effective way of engaging children in literary reading is family reading. Unfortunately, fiction books seem to be an extinct phenomenon in many families, therefore, transforming the problem of reading from the methodological to the social one. Parents themselves are less interested in developing positive reading behavior in their children, since they do not view reading as an important sphere of upbringing. Family reading allows parents to discuss moral aspects of concrete life situations with their children, gives them a chance to be heard, to establish spiritual ties with their children, which in many families are lost forever. It is not accidental that the development of both children and adult reading in many countries (the UK, the USA, Finland, the Netherlands) assumed the scale of state programs, with a number of civil, social, and educational institutions and agencies engaged in its realization.

In conclusion, the effectiveness of engaging students in reading depends on a number of conditions. First of all, the participation of all the stakeholders (students, educators, parents, civic organizations, state and social institutions) in the development of the need for reading and reading motivation is important. Secondly, it is necessary to keep searching for the attractive forms and methods of organizing reading not only during literature, but also other classes, as well as in the process of extracurricular activities organized by supervising teacher, and, certainly, in families.

Modern methodology of teaching literature sees social and pedagogical interaction as a means of developing interest in reading at present and in the future, which will allow to create individual educational pathways for every student-reader, as well as epi-disciplinary educational programs in reading. The content of the work of developing positive reading behavior in students should be focused on the formation of their reading initiative and promoting positive reading self-image as well as the image of society as "the carrier of the book culture" and the text as a system that incorporates the advances of the spiritual culture of the humanity. 


\section{References}

1. Asmus V. F. Chteniye kak trud i tvorchestvo [Reading as Hard Work and Creative Endeavor]. Voprosy istorii i teorii estetiki. Moscow. 1970. 246 p. (rus)

2. Bogin G. I. Obreteniye sposobnosti ponimat: filologicheskaya germenevtika [Developing Understanding: Philological Hermeneutics]. Retrieved from: http//:www.koob.ru/bogin/hermenevtika. 2006. (rus)

3. Granik G. G., Bondarenko S. M., Kontsevaya L. A. Kogda kniga uchit [When a book teaches]. Moscow. 1991. 256 p. (rus)

4. Isaeva O. O. Teoriya i tekhnolohiya rozvytku chytats'koyi diyal'nosti starshoklasnykiv u protsesi vyvchennya zarubizhnoyi literatury [Theory and Techniques of Developing Reading during High School Foreign Literature Classes]. Kyiv: Vyshcha shkola. 2003. 380 p. (ukr)

5. Krylov N. B., Aleksandrov Ye. A. Ocherki ponimayushchey pedagogiki [Sketches on Understanding Pedagogy]. Moscow: Narodnoye obrazovaniye. 2001. 448 p. (rus)

6. Nikolyenko O. M., Kutsevol O. M. Suchasny urok zarubizhnoyi literatury: posibnyk dlya vchytelya. 5 - 11 klas [Modern Foreign Literature Lesson: a Guide for Teachers. $5^{\text {th }}-11^{\text {th }}$ grades]. Kyiv: Vydavnychiy tsentr Akademiya. 2003. 288 p. (ukr)

7. Svetlovskaya N. N. Kogda i pochemu rebyonku chitat' ne hochetsya [When and Why Does Not a Child Want to Read]. Russkiy yazyk $v$ nachalnykh klassakh: teoriya i praktika obucheniya. Moscow: Izdatel'skiy tsentr Akademiya. 2000. 345 p. (rus)

8. Chudinova V.P. Chitayushchiye deti v mire knizhnoy i elektronnoy kul'tury [Children Who Read in the World of Book and Electronic Culture]. Chelovek chitayushchiy: Homo legens - 2. Moscow. 2000. 664 p. (rus)

9. Appleman D., Graves M. Reading Better, Reading Smarter. Portsmouth: Heinemann. 2011. 144 p. (eng) 
10. Appleman D. Adolescent Literacy and the Teaching of Reading: Lessons for Teachers of Literature. National Council of Teachers of English. 2010. 116 p. (eng)

11. Hwang D., Embi M. A. Approaches Employed by Secondary School Teachers to Teaching the Literature. Bangi: Universiti Kebagsaan Madaysaan. 2007. (eng)

\section{Недайнова Т. Б. Чи охопила криза літературну освіту школярів?}

У статті проаналізовано зміни, що відбулися в організації читання школярів у зв'язку з кризою шкільної літературної освіти, у результаті якої 3'являється новий тип читача, для якого характерне прагматичне ставлення до читання, низька читацька самостійність, небажання читати. До перспективних форм і методів подолання кризи відносять розробку індивідуальних освітніх маршрутів школяра-читача, створення надпредметних освітніх програм, розвиток читацької культури, формування позитивного ставлення до читання, відродження традицій домашнього читання. Рішення проблеми читання вимагає визнання ऑii соціального характеру та залучення до іiі вирішення i вчителів, і батьків, представників громадських організацій.

Ключові слова: читацька культура, індивідуальний освітній маршрут школяра-читача, традиції сімейного читання, літературний розвиток школярів, загальнокультурний розвиток.

\section{Недайнова Т.Б. Охватил ли кризис литературное образование} учеников?

В статье проанализированы изменения, произошедшие в организации чтения школьников в связи с кризисом школьного литературного образования, в результате которого появляется новый тип читателя, характеризующегося прагматическим отношением к чтению, низкой читательской самостоятельностью, нежеланием читать. К перспективным формам и методам преодоления кризиса относят разработку индивидуальных образовательных 
маршрутов школьника-читателя, создание надпредметных образовательных программ, развитие читательской культуры, формирование положительного отношения к чтению, возрождение традиций домашнего чтения. Решение проблемы чтения требует признания ее социального характера и привлечения к ее решению не только учителей, но и родителей, представителей общественных организаций.

Ключевые слова: читательская культура, индивидуальный образовательный маршрут школьника-читателя, традиции семейного чтения, литературное развитие школьников, общекультурное развитие.

\section{Nedainova T. B. Is Secondary School Literature Education Going through} a Crisis?

The article draws the attention to the crisis in the literary education of secondary school students, the existence of which has been proved in numerous research studies. The author believes that, over the past years, a new type of reader, characterized by the pragmatic attitude to reading and low reader's independence, has emerged. At the same time, nowadays readers have complete freedom to choose what material to read (technical, medical, political literature, etc.). This leads to the conclusion that the crisis is not so much about reading in general, but about reading classical literature.

Among the forms and methods that can be effective in engaging students to reading classical literature and maintaining positive reading self-image are designing individual educational pathways for students-readers (which accommodate student's interests and needs), establishing epi-disciplinary educational programs, etc. Reviving family reading traditions is also beneficial in this regard, contributing to the establishment of the spiritual bond among family members.

The author believes that reading should be seen as part of a broader social agenda. Therefore, not only schoolteachers or librarians should be expected to act toward it, but also families, social institutions and organizations. 
Key words: reading culture, individual educational pathway of a student-reader, family reading traditions, students' literary development, overall cultural development.

Peer review: Halych O. A. The article was received by the Editorial Office on 07.08.2013

The article was put into print on 30.08.2013 